This is an electronic reprint of the original article. This reprint may differ from the original in pagination and typographic detail.

Author(s): Soler-Carbonell, Josep; Saarinen, Taina; Kibbermann, Kerttu

Title: $\quad$ Multilayered perspectives on language policy in higher education : Finland, Estonia, and Latvia in comparison

Year: $\quad 2017$

Version:

Please cite the original version:

Soler-Carbonell, J., Saarinen, T., \& Kibbermann, K. (2017). Multilayered perspectives on language policy in higher education : Finland, Estonia, and Latvia in comparison. Journal of Multilingual and Multicultural Development, 38(4), 301-314. https://doi.org/10.1080/01434632.2016.1198356

All material supplied via JYX is protected by copyright and other intellectual property rights, and duplication or sale of all or part of any of the repository collections is not permitted, except that material may be duplicated by you for your research use or educational purposes in electronic or print form. You must obtain permission for any other use. Electronic or print copies may not be offered, whether for sale or otherwise to anyone who is not an authorised user. 


\title{
Multilayered perspectives on language policy in higher education: Finland, Estonia and Latvia in comparison
}

\author{
Josep Soler-Carbonell, Stockholm University \\ Taina Saarinen, University of Jyväskylä \\ Kerttu Kibbermann, University of Latvia
}

Final draft May 12, 2016

\begin{abstract}
This article analyses language policies in higher education in Finland, Estonia and Latvia, as well as the European Union. We take a multilayered approach to language policies in order to illuminate the complex and intertwined (and sometimes contradictory) nature of local, national and international language policies in higher education. We are particularly interested in the construction of national or local language(s) and the language(s) of internationalisation in our case countries. Finland, Estonia and Latvia share common features as relatively small non-Anglophone countries in the Baltic region, while simultaneously having somewhat differing political and cultural histories. The results of our discursive analysis indicate that while the three countries have relatively different national language policies, regarding e.g. the position of the national language(s), the institutional policies are more similar in the three cases. For universities, the positioning of English as the de facto language of internationalisation turns the ideology of language choice in higher education into a practical rather than political question. However, at the state level, the promotion of English runs contrary to national policies. The European Union higher education language policy seems to acknowledge the institutional level's practical demands of English as de facto language of internationalisation rather than follow its own formal language policy of official languages.
\end{abstract}

Keywords: higher education; internationalisation; language policy; multi-layered policy

\section{Background and motivation}

Prompted by the need and desire to adapt to a rapidly changing environment, many European universities as well as state and governmental institutions have drafted their own (language) policy documents and programmes. In many cases, from a sociolinguistic point of view, a key emerging concern that runs through these documents is how to find a balance between the status and use of the English language together with the national language(s) (e.g. Björkman, 2014; Lasagabaster, 2015). The heart of the question seems to be that higher education institutions are perceived by many as the guarantors of the maintenance and development of national cultures and languages, though at the same time they are expected to operate and be competitive at an international scale (Cots, Lasagabaster \& Garrett, 2012). However, interestingly enough, even if the centrality of the language question in the process of the internationalisation of higher education seems obvious, in many of these policy documents, language becomes blurred. This is at least the case in Finland (Saarinen, 2012), and seems to be replicated in Estonia too (Soler-Carbonell, 2015).

Our main purpose in this paper is to provide an analysis of several key higher education policy documents on the institutional and state-level in Finland, Estonia, and Latvia, in order to see how the language question at higher education is handled in these three countries. Finland, Estonia and Latvia are geographically closely situated and relatively small non-Anglophone countries that share historical, cultural and political links. Finland has commonly been looked at in the Nordic context, and Estonia and Latvia in the Baltic comparison; shaking up the traditional division might provide new insights. Additionally, Estonia and Latvia often compare themselves with and position themselves among the 
Nordic countries. Whereas Finland has been on the forefront of internationalisation for a while now, the recent growth in English-medium teaching has been particularly rapid in the Baltic countries. When taking into account the share of universities in the country that offer programmes in English and the share of total student enrolment in them, the Nordic countries as well as the Baltic countries stand out in Europe (Lam \& Wächter 2014: 17).

Indeed, in this paper, we also take into consideration EU higher education policy documents in an attempt to map the different discursive constructions around the language question by a variety of relevant stakeholders in the field. In so doing, we consider the fact that language policy and language policy making is a multi-layered process, taking place at different levels (e.g. Halonen, Ihalainen, \& Saarinen, 2015). Thus, in the analysis we include three different layers of language policymaking: the supra-state level, the state level, and the institutional level. Our analysis highlights the interconnectedness and circularity of language policy-making by tracing the recurring themes that appear in the documents produced by these different institutions, highlighting commonalities and differences. This approach makes visible the apparent frictions and inconsistencies between different policy sectors and levels, highlighting this particular nature of policy making: rather than approaching (language) policy as a linear continuum, we acknowledge the temporally and spatially fluid nature of policy (Halonen, Ihalainen \& Saarinen 2015).

The main question we seek to answer in our paper is the following: What is explicitly and what is implicitly mentioned in the analysed documents in relation to: the national language(s), other societal language(s), and English? Our analysis provides an indication of how higher education policy makers frame the language question in the three countries and at the EU level. It shows the tensions and ambiguities that emerge in each of the three settings in relation to the regulation of language in presentday higher education.

\section{The higher education systems of Finland, Estonia and Latvia: a brief overview}

The first Finnish university was founded in Turku during the Swedish rule in 1640. The Royal Academy of Turku was later moved to the new capital, Helsinki, and renamed the Imperial Alexander University, and later the University of Helsinki. By the time of Independence in 1917, technical, economic and fine arts institutions had been founded to complement the multi-disciplinary university. However, Independence made visible the issues between the two official languages (Finnish and Swedish), and new multi-disciplinary universities were founded partly on language policy basis. Also the University of Helsinki went through some language policy debates during the 1920s and 1930s, which illustrated the language policy feuds in the society. After the Second World War, language issues were replaced by policies of regional expansion and structural development in the HE. However, in the 1990s and 2000s internationalisation brought languages back into the HE policy agenda (Saarinen, 2014). During the last decade, Finnish higher education has gone through some profound legislative and structural changes. Numbers of universities and universities of applied sciences have been reduced and the legal status of universities has been changed into public law entities or private foundations, whereas the universities of applied sciences have mostly been turned into limited companies. These processes challenge Finnish higher education from the fundamental perspective of universities as national institutions (providing a public service) in a globalizing world (Saarinen, 2014). All higher education institutions are either Finnish, Swedish or bilingual, thus reflecting the constitutional bilingualism of the country. Since the latest changes in higher education legislation, the institutions have gotten more autonomy in defining language of tuition and degrees. (For a more detailed description, see Saarinen, 2014).

In Estonia, the oldest university, University of Tartu, was founded in 1632 under the Swedish Grand Duchy. In 1919, shortly after the country had gained independence, the university became the first one where instruction took place in Estonian. Estonian retained a relatively prominent role in higher education 
during the years of independence as well as during most of the time when the country was under Soviet rule. A good number of $\mathrm{PhD}$ dissertations, for example, were written in Estonian, although Russian was also used to an extent (Soler-Carbonell, 2014). Over the last twenty years, the range of structural changes suffered by Estonian higher education has been significant (Saar \& Mottus, 2013). As an illustration of such drastic changes, in the academic year 1990-1991, there were only six public universities in Estonia. By 2002, the number had raised to 49 institutions, both public and privately owned, and at present there are 24 higher education institutions in the country (Ministry of Education and Research, 2015). From a language policy point of view, the Universities Act (1999) establishes that the language of instruction in Estonian public universities shall be Estonian, though it allows university councils to freely decide on when and to what extent other languages can be used for that matter.

In Latvia, the first institutions of higher education were established in the 19th century under the rule of Tsarist Russia. As in Estonia, the national university, University of Latvia, was founded in 1919 after the country gained independence. At present, there is a plethora of higher education institutions in Latvia, altogether 56; 36 of them are funded by the state. The number of higher education institutions has grown rapidly since the beginning of the 1990s, and there are no definite plans for limiting it. State-funded higher education institutions are subject to governmental language policy, which defines their language of instruction quite precisely. The Education Law (1998) and the Law on Institutions of Higher Education (1999) stipulate that the main language of instruction should be Latvian; any programme may teach $20 \%$ of courses in other official languages of the EU. In addition, these languages can be used in programmes intended for foreign students or implemented within international cooperation. What seems a bit strict in the light of Finnish and Estonian policies is that in Latvia, BA and MA theses have to be written in Latvian. These regulations were adopted by the parliament in 2006, previously only Latvian medium instruction was possible in state-funded universities. Interestingly, governmental language policy strongly supports the use of Latvian in state-funded universities but by now English-medium instruction is spreading at a faster pace in Latvian academia than in Estonia (Kibbermann, 2014). Private higher education institutions are commercial companies or foundations, subject to the Commercial Law (2002) or the Associations and Foundations Law (2004) that do not regulate their language use.

\section{Theory, data and method}

Increased attention has recently been paid to the analysis of universities as sites of complex connections between language, politics, power, and identity (e.g. Haberland \& Mortensen, 2012; Hultgren Thogersen, $\&$ Gregersen, 2014). Higher education institutions are expected to engage in internationalisation to increase their competitiveness and impact (e.g. Coleman, 2006; Woodfield, 2010). The growing presence of English in teaching (Wächter \& Maiworm, 2014) and research publication (Lillis \& Curry, 2010) has become a source of concern for many stakeholders. This is particularly true in the Nordic countries (Hultgren et al. 2014), since English has made important inroads in the societies of these countries also outside the academia (Hult, 2012). Increasingly, this seems to be the case also in the Baltic states, although their level of engagement with English in higher education has become apparent only more recently (Wächter \& Maiworm, 2014). By contrast, Finland has applied policies for internationalization of higher education for almost three decades (Nokkala, 2007; Saarinen, 2014). This does not strike as particularly surprising, given that back in the late 1980s and early 1990s, the Baltic countries were to a great extent busy with their transition towards re-independence (Hogan-Brun et al., 2007).

At present, in the 'post-national' era (Mortensen \& Haberland, 2012), universities are increasingly playing a more prominent role in the "knowledge society" (Saarinen, 2012). Consequently, English has become visible in enabling higher education institutions to adapt themselves into the changing environment. Mobility, be it of teachers, administrative staff or students, is a keyword of present day universities (Llurda et al., 2014). Thus, universities are offering a growing number of courses and degree programs 
(particularly at the master's and doctoral levels) partially or entirely in English (Wächter \& Maiworm, 2014), in parallel with or at the expense of local or national language(s). Several authors have highlighted the struggle that this represents from an ideological and language-policy point of view. In a Danish context, Hultgren (2014) for instance, finds that 'parallel language use' might imply 'more Danish' for state-level institutions and 'more English' on the institutional level.

With these issues in mind, we propose to examine the tensions and ambiguities that arise from the legislative and strategic treatment of the respective national language(s) on one hand and the introduction of English, on the other, in the HE systems and institutions of Finland, Estonia, and Latvia. Since the three countries and their university systems do not operate in isolation, we also include a European Union level policy theme of the internationalisation of higher education. Our objective, therefore, is to identify the themes that emerge in relation to language and its status at three different layers of policy-making: the supra-state level, the state level, and the institutional level.

Next, we provide information about our data and our methodological approach. The supra-state level is represented by the European Commission document European Higher Education in the World (2013), which contributes to the objectives of the Europe 2020 strategy from the point of view of internationalisation of higher education. Our state level document data consist of documents on higher education strategy and internationalisation. As non-binding documents but rather strategically steering ones, these papers are all the more relevant to our analysis, since they are likely to contain more politically-oriented views to the issues we want to discuss.

The Finnish state level documents are (1) The internationalisation strategy for higher education (2009) (henceforth Internationalisation strategy), which was drafted just prior to the renewal of the Universities Act (2009) and (2) the Development Plan for education and research (2011) (henceforth Development Plan), which is a steering document accepted every four years by the Council of State for the next fiveyear period.

Estonian documentation consists of 1) the Estonian Higher Education Internationalisation Strategy 20062015 (MER, 2006, henceforth Internationalisation Strategy), and 2) the Estonian Lifelong Learning Strategy 2020 (MER, 2014, henceforth Lifelong Learning Strategy). Both are authored by the Ministry of Education and Research.

Unlike Estonia and Finland, Latvia has not yet drafted a strategy for the internationalisation of its higher education system. The Latvian state-level data include 1) the Concept of the Development of Higher Education and Higher Education Institutions for 2013-2020 by the Council of Higher Education and (2) the National Development Plan of Latvia for 2014-2020, authored by the Cross-Sectoral Coordination Centre and approved by the parliament in 2012. The National Development Plan (henceforth the NDP) is the highest national-level medium-term planning document that aims to summarize the state priorities and main areas of action.

We complement the supra-state and state level documentation with institutional language policies from multi-disciplinary universities that have a significant role in the higher education system of the country. The Language Principles of the University of Helsinki (UH 2014) have their starting point in the particular role of the University of Helsinki as the academic flagship organisation of bilingual Finland. The Language Principles of the University of Tartu 2009-2015 were produced as part of the University of Tartu Strategy Plan 2009-2015. The Language Policy of the University of Latvia was adopted by the University of Latvia in 2010.

Most documents were directly available in English, with official translations available to us; here, our text examples have been drawn from the English versions. Only in the case of the Latvian Concept of the 
Development of Higher Education and Higher Education Institutions for 2013-2020 and the Language Policy of the University of Latvia no official translation was available; here, the equivalent keyword in Latvian was used instead.

Table 1 summarises our document data.

Table 1: Higher education (language) policy documents in Finland, Estonia and Latvia

\begin{tabular}{|c|c|c|}
\hline & $\begin{array}{l}\text { Year of } \\
\text { publication }\end{array}$ & $\begin{array}{l}\text { Length in } \\
\text { number of } \\
\text { words }\end{array}$ \\
\hline \multicolumn{3}{|l|}{ Finland } \\
\hline Education and Research 2011-2016. A development plan & 2012 & 25662 \\
\hline $\begin{array}{l}\text { Strategy for the Internationalisation of Higher } \\
\text { Education Institutions in Finland 2009-2015 }\end{array}$ & 2009 & 13952 \\
\hline $\begin{array}{l}\text { Language policy of the University of Helsinki: From } \\
\text { Guidelines to practice }\end{array}$ & 2014 & n.a. \\
\hline \multicolumn{3}{|l|}{ Estonia } \\
\hline $\begin{array}{l}\text { Strategy for the Internationalisation of Estonia's Higher } \\
\text { Education 2006-2015 }\end{array}$ & 2006 & 6133 \\
\hline The Estonian Lifelong Learning Strategy 2020 & 2014 & 9861 \\
\hline $\begin{array}{l}\text { The Language Principles of the University of Tartu } \\
2009-2015\end{array}$ & 2009 & 898 \\
\hline \multicolumn{3}{|l|}{ Latvia } \\
\hline $\begin{array}{l}\text { The Concept of the Development of Higher Education } \\
\text { and Higher Education Institutions for 2013-2020 }\end{array}$ & 2013 & 30267 \\
\hline National Development Plan of Latvia for 2014-2020 & 2014 & 23432 \\
\hline $\begin{array}{l}\text { Language Policy of the University of Latvia (Latvijas } \\
\text { Universitätes valodas politika) }\end{array}$ & 2010 & 570 \\
\hline \multicolumn{3}{|l|}{ EU } \\
\hline European Higher Education in the World & 2013 & 6478 \\
\hline
\end{tabular}

We have conducted a qualitative content analysis (Mayring, 2000) of all the documents, following a 'directed' approach (Hsieh and Shannon, 2005). In line with Mayring (2000), we analysed deductively the selected documents looking for the keywords pertinent to our research questions and theoretical 
framework. Our specific keywords (or categories, following Mayring, 2000) that we deemed relevant for each particular document were references to particular national and other languages: Finnish, Swedish, English, Estonian, Latvian, Russian, (minority) language(s), multilingualism, plurilingualism, etc. This allowed us to obtain the relevant themes in connection to language(s) for each document, and to focus on what is explicitly discussed in connection to them. At the same time, we also implemented an inductive analysis to our documents (Mayring, 2000), particularly when looking for absences of the above categories, and thus when issues connected to our research questions were formulated in an indirect manner.

\section{Analysis}

\section{Finland}

In the documents we analysed, Finnish language - one of the two national languages - is seldom mentioned. Of the 47 explicit mentions of 'language' (Finnish 'kieli' and its derivatives) in the Development Plan, Finnish is not mentioned once. Swedish, by contrast, gets ten mentions in the Development Plan; mostly in a steady discourse of protecting its status in the formally bilingual system: 'The status of the Swedish language will be guaranteed in integration education.'

In the Internationalisation strategy, Finnish (language) gets two mentions. The first one is, in fact, an illustrative quote, made to stress the importance of Finnish for foreign staff. It seems that credibility is sought for the strategic goals by presenting 'eyewitness accounts': 'I do not feel there is a place for me as a teacher or a professor at the university unless I speak Finnish very well.' (A university researcher)

The second reference to Finnish is in connection with Swedish; incidentally, this is the only mention of Swedish in the strategy. This echoes the constitutional coinage of the two equal national languages (see Pöyhönen \& Saarinen, 2015): 'The monitoring of the programme pays particular attention to activities supporting transition to labour markets, study programmes aimed at non-Finnish students and the teaching of Finnish and Swedish.'

An exceptional example is a quote used to illustrate the internationalisation strategy, construing the stress on national languages as 'self-congratulatory': 'We should move away from a self-congratulatory homogenic culture to genuine appreciation and recognition of the importance of internationality, language skills and multiculturalism.'

This quote in effect says the opposite of the Estonian and Latvian (see next subchapters) examples on the local languages, framing 'homogenic culture' as something unwanted.

Foreign languages is an interesting coinage in Finnish language education policy. The study of foreign languages (at that time mostly English, German, and French) in Finnish secondary and tertiary education begun to decline in the 1990s, but the term foreign languages remained to refer to languages other than Finnish and Swedish. Foreign gets several mentions in both documents, but as previous work by Saarinen $(2012,2014)$ shows, in higher education contexts foreign mostly refers to the programmes offered for international students, which are in practice conducted in English.

English, in turn, is only rarely mentioned explicitly in either of the national level documents. It is mentioned twice in both documents, mainly from the point of view of its dominance over other foreign languages: 'In proportion to the size of our higher education sector, there is an exceptionally large amount of teaching available in English.' (Internationalisation strategy) 
The Development Plan, however, has a somewhat paradoxical relationship to English. On the one hand, the dominant position of English in the comprehensive and upper secondary school is discussed as a problem: 'In view of this, language learning in the comprehensive and upper secondary schools has been overly focused on the English language.' (Development plan)

On the other hand, as subject teacher training is discussed, it is proposed that while the number of subject teachers should be reduced, English and physical education are exceptions. Thus, it seems that while the dominance of English is construed as potentially (ideologically) problematic, English is simultaneously seen as a practical requirement that needs to be supported politically.

At the institutional level, the situation becomes slightly different. In the University of Helsinki Language Principles from 2014, bi- and multilingualism are seen as a resource and strength to all actors. An equal starting point is the university's stated responsibility for national languages, Finnish and Swedish. The third starting point introduces English into the language palette by framing it as the lingua franca of international academic co-operation, while at the same time reminding the reader about the value of 'other' languages.

The goals of the University of Helsinki 2014 Language Principles focus on three main aspects. First, the language sensitivity of the university actors needs to be increased, meaning the use of languages needs to be flexible and sensitive to circumstances, and languages need to be used in a parallel fashion. Second, the position of national languages needs to be secured as languages of teaching and communicating about research. And third, the language policy responds to challenges of internationalisation, and draws practices for teaching and research in different languages. While English is not mentioned explicitly in the goals, it is obvious from the presentation of the background that it is the first language of internationalisation.

From the angle of internationalisation, then, English is framed as the de facto third language of the university. Teaching is construed as multilingual (Finnish, Swedish, and English), and it is also expected that in many situations these can be used simultaneously. However, while the policy states the University's responsibility for the national languages, only Swedish is mentioned explicitly referred to as needing 'securing'.

The three documents form a relatively clear continuum in that particularly Swedish, but also the coinage of 'national languages' (though not Finnish explicitly) are presented as needing 'securing'. This is in line with the longer historical continuum of construing Swedish in need of support and security (see Pöyhönen $\&$ Saarinen, 2015, for a discussion of the 'protection discourse'). Finnish language, on the other hand, is even more rarely mentioned, implying perhaps that it is the norm that does not need specific protection. It seems that on the political level, Finnish is not perceived to be in an endangered position even when internationalisation is concerned. Here, Finland seems to differ from Estonia and Latvia (see next subchapters). Finally, the position of English as the academic lingua franca becomes more explicit as we move towards the institutional level. Even at this level, where English becomes explicit, it is framed as a practical question rather than a political one.

\section{Estonia}

Both the Internationalisation Strategy and the Lifelong Learning Strategy share one common goal: the protection, promotion, and development of the Estonian language. The Internationalisation Strategy, for instance, states: 'in opening up Estonian higher education and introducing the international dimension into every curriculum, we must ensure the preservation of the Estonian language as the primary language of teaching and research at institutions of higher education.' 
The other feature that the two documents share is the lack of explicit references to English, much like we have seen in the Finnish case above. It is only explicitly referred to in the Internationalisation Strategy three times, and not a single time in the Lifelong Learning Strategy. Instead, the keyword 'foreign language(s)' is much more frequently used in the Internationalisation Strategy (19 times), and it also appears in the Lifelong Learning Strategy (3 times). This would seem to imply that 'internationalisation' in Estonia is not equated to English only, but instead a more open attitude towards several foreign languages prevails. However, many times the implied 'foreign language' is just one. This is the case, for instance, when reference is made to the need to develop foreign language curricula, since there are almost no curricula offered in a foreign language other than English.

Finally, one important difference between the Internationalisation Strategy and the Lifelong Learning Strategy is in connection to the Russian language. In the former document, it does not appear explicitly mentioned at all, whereas in the latter, it appears four times. When it is mentioned, it is used to refer to the fact that graduates from Russian-medium schools in the country do not have the sufficient Estonian language skills to be competitive in the labour market or to continue their education further at universities or higher education institutions. The document mentions that special support should be given to students graduating from these schools and for students who speak a different 'native' language (a category that is also absent from the Internationalisation Strategy).

Turning to the Language Principles of the University of Tartu 2009-2015, thefirst observation to be made is that this document, unsurprisingly, is much more clearly geared towards language matters at university. Of a relatively short length, the document's goal is to set out the guiding lines that should govern the status of the different languages at the University of Tartu. Similarly to the two other documents analysed above, the Language Principles seems to concentrate thoroughly on the need to protect, promote, and develop the Estonian language, to prevent a full transition to a different language in any field of knowledge, to develop the necessary specialized terminology in Estonian for all areas, and to give the opportunity to all members of the university whose L1 is not Estonian to learn the language.

Indeed, the keyword 'Estonian' (with reference to the language) appears 25 times in the document, whereas 'English' and 'foreign language(s)' appear eight times each; 'Russian' is not mentioned in the document. Interestingly, however, although 'English' and 'foreign language(s)' are mentioned explicitly the same amount of times, it is worthwhile noting that 'English' appears more times in this shorter document than in the other two documents analysed above, which are much longer. Indeed, one of the basic standpoints of the Language Principles of the University of Tartu states that "Language competence - fluency in the native language, the official language and various foreign languages - is a key competence necessary for professional success; in the academic world, the English language has become the lingua franca" (UT Language Principles).

Thus, when English is mentioned explicitly, the document refers to it as an important language, which university graduates and employees should know in order to be competitive in the labour market. At the same time, it is sometimes also mentioned in connection to the idea that 'English is not enough', and that multilingualism with English and other languages is an objective to be pursued: "Create the conditions to enable students to study at least one foreign language in addition to English" (UT Language Principles).

Finally, as in the case of the Internationalisation Strategy, 'foreign language(s)' remains here an ambiguous label. Indeed, although it is used in the plural, in many cases its meaning is once again rather singular, such as when talking about the need to 'promote the development of curricula in foreign languages on all levels' (Language Principles). Apart from the relatively reduced number of curricula in, for example, Germanic, Romance, and Slavonic philologies, all other curricula at UT in a foreign language are officially English-taught programmes. 
All in all, although our analysis here is centred on the three documents that we have examined, the trends that we detect are in line with the bulk of (language) policy documents in the country (for a more detailed policy analysis of other documents in Estonian higher education, see Soler-Carbonell, 2015). In sum, policies regulating language and education issues in the country, especially regarding the internationalisation of higher education, are particularly concerned with the protection, promotion, and development of Estonian. In other respects, the language question does not appear as clearly and explicitly formulated, and indeed, the use of the 'foreign language' label produces more ambiguities than clarifies anything else.

Latvia

In the National Development Plan of Latvia for 2014-2020 (henceforth the NDP), language is seldom mentioned in the document - 17 times. Latvian is mentioned 5 times and foreign language - 3 times. Foreign languages are not named.

Similarly to Estonian policy, Latvian governmental policy also construes the Latvian languages as the language in need of state-aided protection, promotion and development. The NDP views Latvian as 'the fundamental national treasure', and Latvia as 'the only country in the world where the Latvian nation, language and culture can exist and fully develop'. In addition, Latvian is defined as the language that could and should unite the society in Latvia. Social integration based on Latvian has been a long-term aim of the state language and integration policy. Although minority language speakers, that constitute about 30 per cent of the total population, have a good command of Latvian (only 10 per cent of the inhabitants do not speak any Latvian), both Latvians and minorities often opt for Russian in everyday interethnic communication (Latvian Language Agency, 2016, in press). Thus, the acquisition and use of Latvian should be further promoted in order to provide the basis for social integration, a goal not yet reached, as implied by the NDP. As a result, the NDP stresses that a 'coordinated system for the acquisition of the Latvian language for children and adults' should be created that would 'encourage the use of Latvian in public' and strengthen 'the position of Latvian in everyday communication'. At the same time, the NDP also claims that the strength of Latvia lies in the knowledge of other languages too. Thus, it stresses that Latvian as well as foreign languages 'are the pillars of the education system', and children should have 'the knowledge of at least one foreign language'.

When it comes to higher education, internationalisation is set as a goal to reach. Here too, the NDP points out the value of the Latvian language, which is to remain the main language of instruction in higher education. In addition, other official languages of the EU are encouraged to be used. Interestingly, the previously mentioned 'foreign languages' become 'the official languages of the EU' in higher education, excluding Russian from becoming a potential medium of instruction at tertiary education.

(In 2020) Latvia has internationally competitive colleges and universities employing internationally recognised and qualified academic staff. Higher education has become a widely coveted export service of Latvia. Study programmes are provided in accordance with the language policy of Latvia as a national state: primarily in Latvian and in one of the official languages of the European Union.

The Concept of the Development of Higher Education and Higher Education Institutions for 2013-2020 (Council of Higher Education, 2013, henceforth the Concept) has been drawn up to work towards the long-term aim of the Latvian higher education policy that is defined in the same document. The aim is to create such a system that would ensure the development of the state, its economy and higher education (parallel to developments in Europe). Connecting the tertiary education of Latvia to that of 
Europe raises many language-related questions that remain largely fielded on the 110 pages of this document. Language (Latvian 'valoda' and its derivatives) is rarely mentioned - only 9 times (among which we find the only one mention of Latvian, 'latviešu valoda').

The Concept discusses the internationalisation of higher education thoroughly, arguing that internationalising Latvian higher education at different levels (including the language of instruction) is crucial for its development. However, the document does not discuss in greater detail the language-related issues of internationalisation. The rest of the mentions of language have to do with stating that internationalisation has to take place according to the official language policy of the state - studies at universities should be carried out mostly in Latvian and partly in other official languages of the EU. The Concept stresses that it is important to develop programmes in the official languages of the EU, although, at the same time, foreign students' interest towards the Latvian language and culture should be stimulated by creating special scholarships.

Neither the NDP, nor the Concept name the official languages of the EU which are encouraged to be used, hinting that all the official languages of the EU are equal in that sense. Although the Concept rarely mentions language issues at all, it draws attention to the need to draft a strategy for the internationalisation of Latvian higher education.

The state documents do not say much in detail how to find a balance between internationalisation and accompanying influx of English, and the maintaining and developing of Latvian as the language of higher education. In order to deal with questions that rise in everyday practice, the University of Latvia has adopted its own language policy guidelines - Policy of Languages of the UL (UL, 2010) - that focus on connecting the national and international interests. In this short document, there are 48 mentions of language (Latvian 'valoda' and its derivatives), 23 mentions of the Latvian language ('latviešu valoda' and its derivatives), 8 mentions of English ('angl̦u valoda' and its derivatives) and 5 mentions of foreign language ('svešvaloda' and its derivatives). Thus, the main focus of this document is on Latvian; however, in comparison to the previously analysed state documents, the language policy guidelines of the UL explicitly refer to English, and leave the implicit phrase of the official languages of the EU entirely out of its text.

The main aim of the document is to search for a balance between the use of Latvian, i.e. the official language, and English, whose importance is defined through its status as an internationally acknowledged scientific language.

The aim of the policy of languages of the University of Latvia is to: 1.1. enhance its academic staff's and students' skills of the Latvian language, i.e. the official language, and the English language, i.e. the internationally acknowledged language of scientific communication.

Thus, Latvian is defined as being important because it is the official language of the country, and the UL as the national university is responsible for its maintenance and development. Whereas the language policy guidelines of the UL mostly speak about Latvian as a language which use has to be maintained and guaranteed, English is often put in the light in which its acquisition and use has to be enhanced, expanded and broadened. Altogether, language skills, especially in English, are depicted as a necessary prerequisite for professional development in today's world, just as in Finland and Estonia.

\section{European Union}

The EU policy document analysed here (European Higher Education in the World, European Commission, 2013) is a rather short document (slightly above 6000 words), and the language question 
does not appear as particularly prominent in it. 'English' is explicitly mentioned 4 times, 'language(s)' 9 times and 'multilingualism' only once.

By contrast, 'higher education' appears 54 times, and 'internationalisation' 40 times. The document is clearly about the internationalisation of higher education, but strikingly, language does not seem to play a very significant role for EU policymakers in the context of higher education internationalisation. This, however, is nothing new, and it has been observed in other European higher education policy documents, such as the Bologna Declaration (e.g. Phillipson, 2015).

The document, however, explicitly acknowledges the relevance of English in the context of the internationalisation of higher education, and although it also places emphasis on the promotion of multilingualism, defined as a 'European asset', this explicit reference to English is not so frequently found in EU policy discourse (Nikula et al., 2012). This is a somewhat surprising direct reference to English in the context of a EU policy document:

On the one hand, proficiency in English is de facto part of any internationalisation strategy for learners, teachers and institutions and some Member States have introduced, or are introducing, targeted courses in

English (especially at Masters level) as part of their strategy to attract talent which would otherwise not come to Europe. On the other hand, multilingualism is a significant European asset: it is highly valued by international students and should be encouraged in teaching and research throughout the higher education curriculum.

In this document, mobility seems to be an issue of particular concern, and when it comes to 'language', it can be read in two different directions: mobility that is motivated by languages, and languages (or language teaching and learning) that is motivated by mobility. In other words, on the one hand, mobility leads to the acquisition of different skills and competences, including linguistic ones; on the other hand, institutions need to be aware of the importance of catering for good services for mobile students and scholars, including linguistic services too:

Mobility concerns more than students: staff mobility brings manifold benefits to the institution and individual. It is an instrument for the acquisition of new competences, languages and teaching methods and forges international networks.

Mobility, and in particular credit mobility, should be used as a strong incentive for improving the quality of European higher education. HEIs should develop better services to send and receive international students or researchers, including individual counselling to advise on career paths and to facilitate integration into the city/region/country, with language training where appropriate.

Finally, and as in many of the other country documents analysed here, the EU policy document contains several vague references to 'language(s)', as seen in the previous two extracts as well as in the following example: 'Integrating an international dimension in curricula highlights the importance of languages.' Which language in particular, for what purposes, etc., is something that is left unmentioned, and this, as with the 'foreign languages' label, is likely to lead to more ambiguities and uncertainties. The same ambiguity is present in the country cases described above, supporting Harder's (2012) observation of 'soft multilingualism'; i.e. language policy where "all languages should be allowed and none prescribed". This contradicts the explicit language policy of the European Union where the Member state languages are supported over others (Nikula et al., 2012). 
Table 2 summarizes the analysis of the languages mentioned, the status of the national language(s) in the documents, and the motivations to mention other languages.

Table 2: Overview of comparisons of Finland, Estonia and Latvia

\begin{tabular}{|c|c|c|c|}
\hline & $\begin{array}{l}\text { Languages } \\
\text { mentioned } \\
\text { explicitly }\end{array}$ & $\begin{array}{l}\text { Motivation for } \\
\text { national languages }\end{array}$ & $\begin{array}{l}\text { Motivation for other } \\
\text { languages }\end{array}$ \\
\hline \multicolumn{4}{|l|}{ Finland } \\
\hline $\begin{array}{l}\text { Education and Research } \\
\text { 2011-2016. A development } \\
\text { plan }\end{array}$ & $\begin{array}{l}\text { Swedish, } \\
\text { English }\end{array}$ & $\begin{array}{l}\text { Swedish in need of } \\
\text { protection. }\end{array}$ & $\begin{array}{l}\text { Dominance of } \\
\text { English, but also need } \\
\text { for English. } \\
\text { "Foreign" as } \\
\text { euphemism for } \\
\text { English }\end{array}$ \\
\hline $\begin{array}{l}\text { Strategy for the } \\
\text { Internationalisation of } \\
\text { Higher Education } \\
\text { Institutions in Finland 2009- } \\
2015\end{array}$ & $\begin{array}{l}\text { Firnish, } \\
\text { Swedish, } \\
\text { English }\end{array}$ & $\begin{array}{l}\text { Finnish and Swedish } \\
\text { as national languages }\end{array}$ & $\begin{array}{l}\text { Dominance of } \\
\text { English. } \\
\text { "Foreign" as } \\
\text { euphemism for } \\
\text { English }\end{array}$ \\
\hline $\begin{array}{l}\text { Language policy of the } \\
\text { University of Helsinki: From } \\
\text { Guidelines to practice }\end{array}$ & $\begin{array}{l}\text { Finnish, } \\
\text { Swedish, } \\
\text { English }\end{array}$ & $\begin{array}{l}\text { Finnish and Swedish } \\
\text { as national languages; } \\
\text { Swedish in need of } \\
\text { protection. }\end{array}$ & $\begin{array}{l}\text { English as academic } \\
\text { lingua franca } \\
\text { Value of "other" } \\
\text { languages }\end{array}$ \\
\hline \multicolumn{4}{|l|}{ Estonia } \\
\hline $\begin{array}{l}\text { Strategy for the } \\
\text { Internationalisation of } \\
\text { Estonia's Higher Education } \\
2006-2015\end{array}$ & $\begin{array}{l}\text { Estonian, } \\
\text { English }\end{array}$ & $\begin{array}{l}\text { Estonian in need of } \\
\text { protection }\end{array}$ & $\begin{array}{l}\text { "Foreign languages" } \\
\text { implied as not only } \\
\text { English }\end{array}$ \\
\hline $\begin{array}{l}\text { The Estonian Lifelong } \\
\text { Learning Strategy } 2020\end{array}$ & $\begin{array}{l}\text { Estonian, } \\
\text { Russian }\end{array}$ & $\begin{array}{l}\text { Estonian in need of } \\
\text { protection }\end{array}$ & $\begin{array}{l}\text { "Foreign languages" } \\
\text { implied as not only } \\
\text { English } \\
\text { Russian natives in } \\
\text { need of language } \\
\text { support }\end{array}$ \\
\hline $\begin{array}{l}\text { The Language Principles of } \\
\text { the University of Tartu 2009- } \\
2015\end{array}$ & $\begin{array}{l}\text { Estonian, } \\
\text { English }\end{array}$ & $\begin{array}{l}\text { Estonian in need of } \\
\text { protection }\end{array}$ & $\begin{array}{l}\text { English as lingua } \\
\text { franca } \\
\text { Value of "foreign } \\
\text { languages" }\end{array}$ \\
\hline
\end{tabular}




\begin{tabular}{|c|c|c|c|}
\hline \multicolumn{4}{|l|}{ Latvia } \\
\hline $\begin{array}{l}\text { The Concept of the } \\
\text { Development of Higher }\end{array}$ & Latvian & $\begin{array}{l}\text { Latvian as language of } \\
\mathrm{HE}\end{array}$ & $\begin{array}{l}\text { Study programmes in } \\
\text { official languages of }\end{array}$ \\
\hline $\begin{array}{l}\text { Education and Higher } \\
\text { Education Institutions for } \\
\text { 2013-2020 }\end{array}$ & & & the EU needed \\
\hline $\begin{array}{l}\text { National Development Plan } \\
\text { of Latvia for 2014-2020 }\end{array}$ & Latvian & $\begin{array}{l}\text { Latvian as official } \\
\text { language. } \\
\text { Strengthening the use } \\
\text { of Latvian }\end{array}$ & $\begin{array}{l}\text { Importance of } \\
\text { "foreign languages". } \\
\text { Study programmes in } \\
\text { official languages of } \\
\text { the EU needed. }\end{array}$ \\
\hline $\begin{array}{l}\text { Language Policy of the } \\
\text { University of Latvia (Latvijas } \\
\text { Universitätes valodas politika) }\end{array}$ & $\begin{array}{l}\text { Latvian, } \\
\text { English }\end{array}$ & $\begin{array}{l}\text { Latvian as official } \\
\text { language }\end{array}$ & $\begin{array}{l}\text { Balance between } \\
\text { Latvian and English }\end{array}$ \\
\hline \multicolumn{4}{|l|}{ EU } \\
\hline $\begin{array}{l}\text { European Higher Education } \\
\text { in the World }\end{array}$ & English & $\begin{array}{l}\text { EU policy of } \\
\text { multilingualism }\end{array}$ & $\begin{array}{l}\text { "Additional" } \\
\text { European languages } \\
\text { promoted with an } \\
\text { employment } \\
\text { motivation }\end{array}$ \\
\hline
\end{tabular}

\section{Discussion and conclusions}

Our analysis, while indicating no particular contradictions between the continuum from supra-state to state to institutional language policies in the national cases, showed differences between the conceptualisations of languages particularly in the state-level analysis, and to a smaller degree on the institutional level. The national level documents understandably focus on the formal and explicit ideologies of the state, whereas the institutional policies often refer to 'practical' needs, thus showing a different kind of (more implicit) ideological stand where internationalisation (represented by English language study programmes) is more prevalent.

One aspect of our analysis focused on the position of the national languages in higher education. In Finland the position of the national languages (i.e. Finnish and Swedish) seems to be more or less the same across the levels, which reflects the strong (hygienic even, see Pöyhönen \& Saarinen, 2015) position of societal (rather than individual) bilingualism in Finland. The bilingual Finland's state level documentation explicates Swedish more often than Finnish, discursively constructing the position of Swedish as a minority language more in need of 'protection'. Finnish, in turn, which is spoken by approximately 90 per cent of the population as first language, is not construed in need of protection. This puts Finland in a different position from Estonia and Latvia that have large minority populations and present policies concerned with the 'protection, promotion, and development' of Estonian or strengthening and maintaining the position of Latvian in the country and as a European Union language. In line with Bulajeva and Hogan-Brun's (2014) analysis of Lithuanian HE internationalisation policies, we can observe here a clash between the need to reconcile ethno-centric approaches to language in education policies in the country (in place since re-independence in the early 1990s) with Eurocentric and 
global trends (joining the EU in 2004, signing the Bologna process, etc.). This results in important identity dilemmas: on the one hand, supporting and celebrating multilingualism and multiculturalism, on the other hand strengthening and maintaining the position of the country's official language in higher education.

On the state level, English seems to be construed as 'foreign' both in Finland and Estonia, indicating that while it has a strong position in both countries, the relationship is not unproblematic. At times, 'English' is construed as 'dominant' and possibly problematic. The reference to 'foreign' may also indicate a genuine need to support 'other' languages. This is what Harder (2012) calls 'soft' multilingualism: there are no explicit policies on promoting some languages of internationalisation over others, which leads into a strengthening of an already strong language, in this case English. 'Multilingualism' becomes a label for anything that's not national or (hegemonic) English (Harder 2012).

Latvia, on the other hand, only very generally mentions the use of the official languages of the EU in the internationalisation process with the main aim of avoiding the influx of Russian in its state-funded higher education market. Russian, although a widespread language in Latvia, spoken by almost everyone, is not once mentioned. It becomes totally invisible, it is constructed neither as a threat nor as an opportunity. A similar situation can also be observed in the case of Estonia, where Russian is not referred to explicitly in both state and institutional documents in connection to higher education issues. While both countries are still sensible to their recent historical developments and prefer not to discuss Russian explicitly in (language) policy matters of higher education, it seems that Russian language programmes may be promoted to attract fee-paying Russian students: Russian is prohibited as a language of instruction in state-funded higher education in Latvia (except for Slavic language and culture studies), but private institutions of higher education teach approximately 1 of programmes in Russian (Kibbermann, 2014).

English, however, becomes more explicit on the institutional level, reflecting the problematic relationship between language 'policy' and language 'practice' (see Björkman 2014). At the University of Helsinki, English is framed as an academic lingua franca, making the University of Helsinki de facto a trilingual university. In Estonia, the 'foreign languages' label still appears in the University of Tartu Language Principles, but 'English' becomes more explicit, considered as a pragmatic need. In Latvia, the situation is similar on the university level: the language policy of the University of Latvia presents a practical need to deal with language issues, and 'the official languages of the EU' become concretized as 'English and other foreign languages'. English is viewed as an opportunity and never framed as a threat at the institutional level in Latvia, it offers the university a source of prospective students that are very much needed in the light of decreasing number of local students. These results are in line with Hultgren's (2014) analysis of the Danish case, where 'parallel language use' tends to be dubbed as 'more Danish' by state level institutions, and 'more English' by university policy-makers. This makes the ideological choice of supporting English practical rather than political.

Thus, on the institutional level, Finland, Estonia and Latvia resemble each other more than on the national level. The universities apparently deal with the same issues of internationalisation and the practical questions of choosing the appropriate language, whereas on the state level, the issue is more about following national needs and policies. In this, the Latvian state-level ideology differs quite a lot from Estonia and Finland. Consequently, different national policies may still have similar institutional reactions. The differences on different policy levels also reflect on agents with different agendas. Statelevel public officials are likely to be more concerned about the political effects of language policy and planning issues in connection to language and identity debates. University officials, on the other hand, are likely to be more concerned about making their institutions more competitive on the international scene. The consequences of these ideological and discursive tensions are still largely to be uncovered, but certainly having such seemingly opposed directions on the language question at university may lead to further power struggles in the field, with state officials being more attuned to national discourses about 
languages (which explains the difference between Finland versus Estonia and Latvia at that level), and university officials more in tune with the internationalising needs of their institutions and campuses (which explains the similarities between the three).

The EU level document, which was drafted as part of the European Union 2020 strategy work, is surprisingly explicit in its promotion of English. European Union language policies generally tend to promote 'multilingualism', which often refers to the equal position of the official and a special role of the autochthonous languages (Nikula et al. 2012). Thus, it would appear that the EU level feeds into the ideology of the institutional level rather than the national one.

Our results indicate that language policy and planning in higher education takes place in a complex interaction between different agents and competing ideologies in the field. Policies (in our case language policy) have different inputs from different policy sectors, and looking at an individual sector gives only part of the picture (see Saarinen, 2016 \& articles in the forthcoming special issue of Higher Education on 'Language' indexing higher education policy). The state-level documentation reflects national policies with national needs and link carefully to the national ideological debates. The institutions, on the other hand, take their ideological impetus from internationalisation as well as from national ideologies, making the institutional level an interesting meeting place of official and unofficial views of policy and practice. Language policies are not linear and hierarchical continuums that neatly follow the same logic, but produce different outcomes depending on the actors and interests that surface in different contexts.

\section{Acknowledgements}

We would like to thank the University of Jyväskylä Faculty of Humanities for a travel grant enabling us to work together on a first draft of this article. Research on the Estonian part of this paper was supported by the European Union through the European Social Fund (Mobilitas grant number GFLEE322MJ). We acknowledge the help received from the Latvian Language Agency supporting the participation of the article's third author in the development of the paper.

\section{References}

Associations and Foundations Law 2004. Latvian legislation database Likumi.lv http://likumi.lv/doc.php?id=81050. Accessed January 14, 2016.

Björkman, B. 2014. "Language ideology or language practice? An analysis of language policy documents at Swedish universities." Multilingua 33 (3-4): 335-363.

Bulajeva, T., and G. Hogan-Brun. 2014. "Internationalisation of higher education and nation building: resolving language policy dilemmas in Lithuania." Journal of Multilingual and Multicultural Development 35 (4): 318-331.

Coleman, J. 2006. "English-medium teaching in European higher education." Language Teaching 39 (1): $1-14$.

Commercial Law. 2002. Latvian legislation database Likumi.lv http://likumi.lv/doc.php?id=5490. Accessed January 14, 2016.

Cots, J.M., D. Lasagabaster, and P. Garrett. 2012. "Multilingual policies and practices of universities in three bilingual regions in Europe." International Journal of the Sociology of Language 216: 7-32.

Education Law (1998). Latvian legislation database Likumi.lv http://likumi.lv/doc.php?id=50759. Accessed January 14, 2016.

Haberland, H., and J. Mortensen (Eds.). 2012. "Language and the international university." [Special Issue]. International Journal of the Sociology of Language 216: 1-197.

Halonen, M., P. Ihalainen, and T. Saarinen (Eds.). 2015. Language Policies in Finland and Sweden: Interdisciplinary and Multi-sited Comparisons. Bristol: Multilingual Matters. 
Harder, P. 2012. "Parallel Language Use at the University of Copenhagen - an evolving commitment". Presentation at the CALPIU'12: Higher education across borders: Transcultural interaction and linguistic diversity, April 1-4, Roskilde, Denmark.

Hogan-Brun, G., U. Ozolins, M. Ramoniene, and M. Rannut. 2007. Language politics and practices in the Baltic states. Current Issues in Language Planning 8(4): 469-631.

Hsieh, H., and S. Shannon. 2005. "Three approaches to qualitative content analysis." Qualitative Health Research 15 (9): 1277-1288.

Hult, F. 2012. "English as a trans-cultural language in Swedish policy and practice." TESOL Quarterly 46 (2): $230-257$.

Hultgren, A.K. 2014. "Whose parallellingualism? Overt and covert ideologies in Danish university language policies." Multilingua 33 (1-2): 61-87.

Hultgren, A.K., F. Gregersen, J. Thogersen (Eds.). 2014. English in Nordic Universities: Ideologies and Practices. Amsterdam: John Benjamins Publishing.

Kibbermann, K. 2014. Language Policy in Higher Education in Estonia and Latvia: Regulations and Practices. Via Scientiarum 2: 111-124.

Lam, Q. \& B. Wächter, 2014. Executive summary. In Bernd Wächter \& Friedhelm Maiworm (eds.). English-taught Programmes in European Higher Education. The State of Play in 2014. ACA Papers on International Cooperation in Europe, 15- 24. Bonn: Lemmen.

Lasagabaster, D. 2015. "Multilingual language policy: is it becoming a misnomer at university level?" In The English Language in Teaching in European Higher Education, edited by S. Dimova, A. K. Hultgren and C. Jensen, 115-134. Berlin: Mouton de Gruyter.

Lillis, T., and M. Curry. 2010. Academic Writing in a Global Context. London: Routledge.

Llurda, E., J.M. Cots, and L. Armengol. 2014. "Views on multilingualism and internationalization in higher education: administrative staff in the spotlight." Journal of Multilingual and Multicultural Development 35 (4): 376-391.

Mayring, P. 2000. "Qualitative content analysis.” Forum: Qualitative Social Research 1(2). Art. 20. http://www.qualitativeresearch.net/index.php/fqs/article/view/1089/2385 Accessed 16 December 2015.

Mortensen, J., and H. Haberland. 2012. "English - the new Latin of academia? Danish universities as a case." International Journal of the Sociology of Language 216: 175-197.

Nikula, T., T. Saarinen, S. Pöyhönen and T. Kangasvieri (2012). "Linguistic Diversity as a Problem and a Resource - Multilingualism in European and Finnish Policy Documents." In Dangerous Multilingualism: Northern perspectives on order, purity and normality, edited by J. Blommaert, S. Leppänen, P. Pahta \& T. Räisänen, 41- 66. Houndmills, UK: Palgrave Macmillan.

Nokkala, T. 2007. Constructing the ideal university: the internationalisation of higher education in the competitive knowledge society. Tampere: Tampere University Press.

Phillipson, R. 2015. "English as a threat or opportunity in European higher education." In The English Language in Teaching in European Higher Education, edited by S. Dimova, A. K. Hultgren and C. Jensen, 19-42. Berlin: Mouton de Gruyter.

Pöyhönen, S., and T. Saarinen. 2015. "Constructions of bilingualism in Finnish government programmes and a newspaper discussion site debate." Current Issues in Language Planning 16 (4): 392-408.

Saar, E., and R. Mottus (Eds.). 2013. Higher Education at a Crossroad: The Case of Estonia. Frankfurt: Peter Lang.

Saarinen, T. 2012. "Internationalisation of Finnish higher education - is language and issue?" International Journal of the Sociology of Language 216: 157-173.

Saarinen, T. 2014. Language ideologies in Finnish higher education in the national and international context: a historical and contemporary outlook. In English in Nordic Universities: Ideologies and Practices, edited by A.K. Hultgren, F. Gregersen and J. Thogersen, 127-146. Amsterdam: John Benjamins. 
Saarinen, T. 2016. "Policy is what happens while you're busy doing something else: introduction to special issue on "language" indexing higher education policy". Higher Education. Online First. DOI $10.1007 / \mathrm{s} 10734-016-0002-3$

Soler-Carbonell, J. 2014. "University language policies and language choice among Ph.D. graduates in Estonia: The (unbalanced) interplay between English and Estonian." Multilingua 33 (3-4): 413-436.

Soler-Carbonell, J. 2015. "Language policy in Estonian higher education: internationalisation and the tension over English." In The English Language in Teaching in European Higher Education, edited by S. Dimova, A. K. Hultgren and C. Jensen, 247-268. Berlin: Mouton de Gruyter.

Universities Act 2009. Universities act 558/2009. Finnish legislation database Finlex. http://www.finlex.fi/fi/laki/kaannokset/2009/en20090558.pdf. Accessed January 4, 2016. 